\title{
Siroz Hastalarında, Serum Biyobelirteçlerinin HCC, HRS ve Sağ Kalımla İlişkisi
}

\section{Relationship of Serum Biomarkers with HCC, HRS and Survival in Patients with Cirrhosis}

\author{
Muharrem Keskin ${ }^{1}$
}

\begin{abstract}
Öz
Amaç: Bu çalışmada, serum biyobelirteçlerinin hepatoselüler karsinom (HCC) ve hepatorenal sendrom (HRS) tanılı hastalarda tanı ve sağ kalım ilişkilerinin değerlendirilmesi ayrıca pratikte rutin kullanıma uygunluğun belirlenmesi amaçlanmıştır.

Hastalar ve Yöntem: Bu çalışma, 2005 ve 2020 yılları arası yapılan gözlemsel, retrospektif bir kohort çalışmasıdır. Kontrol grubu olarak sadece siroz tanılı olgular alınmıştır ve bu hastalarda HCC veya HRS tanıları yoktur. Kontrol grubuna ek olarak 3 ayrı grup daha tanımlanmıştır; HCC grubu, HRS grubu ve HCC\&HRS grubu. Kontrol grubuna malign hastalığı olanlar (HCC dışı) alınmamıştır. Hemogram sonuçlarından elde edilen nötrofil, lenfosit ve platelet sayımları kullanılarak tüm hasta grupları için, nötrofil-lenfosit oranı (NLR), nötrofil-platelet oranı (NPR), sistemik immün inflamatuvar indeks (SII) skoru ve CRP'nin albümine oranı (CAR) hesaplandı.

Bulgular: Çalışmaya toplam 110 hasta alınmıştır; hastaların 26'sı $(\% 23,6)$ kadın iken 84 'ü $(\% 76,4)$ erkektir. Siroz grubunda $29(\% 26,4)$ hasta, HCC grubunda $27(\% 24,5)$, HRS grubunda $18(\% 16,4)$ ve HCC\&HRS grubunda ise $36(\% 32,7)$ vardır. Gruplardan bağımsız olarak tüm popülasyonda hastaların 63 'ü $(\% 57,3)$ HCC iken 54'ü $(\% 49,1)$ HRS tanılıdır; HRS hastalarında $36(\% 32,7)$ Tip 1 ve $18(\% 16,4)$ ise Tip 2 hastasıdır. Sağ kalım bakımından değerlendirmede takip sürecinde tüm hastaların 68'i $(\% 61,8)$ kaybedilmiştir (exitus); 27 (tüm hastaların \%24,5'i) hasta ilk 1 yıl içinde kaybedilmiştir. Serum biyobelirteçlerin, HRS tespit etme yeteneklerinin ROC analizleriyle karşılasstırmalarında AUC değeri 0,7 üzerinde saptanmayan tek biyobelirteç SII'dır; >624 eşik değeri için AUC: 0,674 (0,578-0,760). Serum biyobelirteçlerin, tanı gruplarından bağımsız genel sağ kalımı tahmin etme yeteneklerinin ROC analizleriyle karşılaştırmalarında tüm biyobelirteçler için AUC $>0,7$ saptanmıştır; en yüksek sensitivite $(\% 70,59)$ ve spesifisite $(\% 80,95)$ değerleri NLR ve CAR için saptanmıştır.

Sonuç: Serum biyobelirteçleri NLR, NPR, SII ve CAR siroz hastalarında HCC, HRS varlığında genel sağ kalımı predikte etmeye yeterlidirler. Hepatorenal sendromu tespit etme bakımından NLR, NPR ve CAR yeterli sensitivite ve spesifisiteye sahiptir.
\end{abstract}

Geliş Tarihi/Received: 28 Eylül 2021 Kabul Tarihi/Accepted: 11 Kasım 2021

Anahtar Kelimeler: Hepatoselüler kanser, hepatorenal sendrom, biyobelirteçler, NLR, CAR \begin{abstract}
Aim: In this study, it was aimed to evaluate the diagnosis and survival relationships of serum biomarkers in patients with hepatocellular cancer (HCC) and hepatorenal syndrome (HRS), as well as to determine their suitability for routine use in practice.

Patients and Methods: This is an observational, retrospective cohort study; between years 2005 and 2020. Only cases diagnosed with cirrhosis were included as the control group and these patients did not have a diagnosis of HCC or HRS. In addition to the control group, 3 different groups were defined; HCC group, HRS group and HCC\&HRS group. Those with malignant disease (non-HCC) were not included in the control group. Using neutrophil, lymphocyte and platelet counts obtained from hemogram results, neutrophil-lymphocyte ratio (NLR), neutrophil-platelet ratio (NPR), systemic immune inflammatory index (SII) score and CRP to albumin ratio (CAR) were calculated for all patient groups.

Results: A total of 110 patients were included in the study; While $26(23.6 \%)$ of the patients were female, 84 $(76.4 \%)$ were male. There were $29(26.4 \%)$ patients in the cirrhosis group, $27(24.5 \%)$ in the HCC group, 18 $(16.4 \%)$ in the HRS group, and $36(32.7 \%)$ in the HCC\&HRS group. Regardless of the groups, $63(57.3 \%)$ of the patients in the whole population were diagnosed with HCC, while $54(49.1 \%)$ were diagnosed with HRS; $36(32.7 \%)$ patients with HRS were Type 1 and 18 (16.4\%) were Type 2 patients. In terms of survival, 68 $(61.8 \%)$ of all patients died during the follow-up period (exitus); 27 patients (24.5\% of all patients) died within the first year. In comparisons of the HRS detection capabilities of serum biomarkers with ROC analyses, the only biomarker whose AUC value was not detected above 0.7 is SII; AUC for $>624$ threshold: 0.674 (0.578-0.760). Comparisons of serum biomarkers' ability to predict overall survival independent of diagnostic groups with ROC analyzes found AUC $>0.7$ for all biomarkers; The highest sensitivity $(70.59 \%)$ and specificity $(80.95 \%)$ values were determined for NLR and CAR.

Conclusion: Serum biomarkers NLR, NPR, SII and CAR are sufficient to predict overall survival in the presence of HCC, HRS in cirrhotic patients. NLR, NPR and CAR have sufficient sensitivity and specificity to detect hepatorenal syndrome.
\end{abstract}

Key words: Hepatocellular cancer, hepatorenal syndrome, biomarkers, NLR, CAR

Atıf yapmak için: Keskin M. Siroz Hastalarında, Serum Biyobelirteçlerinin HCC, HRS ve Sağ Kalımla İlişkisi. Selcuk Med J 2021;37(4): 313-321
Açıklama: Yazar bu makalede bahsedilen herhangi bir ürün, aygıt veya ilaç ile ilgili maddi çıkar ilişkisine sahip değildir. Araştırma, herhangi bir dış organizasyon tarafından desteklenmedi. Yazar çalışmanın birincil verilerine tam erişim izni vermek ve derginin talep ettiği takdirde verileri incelemesine izin vermeyi kabul etmektedir. 


\section{GíRiş}

Karaciğer sirozu hastalarında, hepatoselüler karsinom (HCC) ve hepatorenal sendrom (HRS) yaşam kalitesini kısıtlayan ve sağ kalım süresini oldukça azaltan majör komplikasyonlardandır. Maalesef günümüzde hâlâ, hem erken tanı elde edebilmek ve farkındalık bakımından hem de sağ kalımı öngörebilmek için net, etkin ve spesifik tetkikler ve belirteçler bulunamamıştır. Mevcut testler ve biyobelirteçler bu boşluğu dolduramamaktadırlar. Özellikle, HRS gelişimini erken predikte edebilecek biyobelirteç ve testlerle ilgili yeterli çalışmalar bulunmamaktadır.

Karaciğerin primer tümörü olan $\mathrm{HCC}$, tüm dünyada kanserden ölümler içinde 4. sırayı alırken düşük gelirli ülkelerde ise kanserle ilişkili ölümlerde başı çekmektedir (1). Hastalığın azalan insidans oranlarına rağmen, mortalite oranları halen yüksek devam etmektedir ve daha iyi sonuçlar elde edebilmek için erken teşhis hayati önem taşımaktadır $(2,3)$. Erken teşhis, hem HCC odağını erken evrede yakalayabilmeyi hem de tümöre yönelik tedavilerin daha etkin ve az maliyetli uygulanabilmesini ve dolayısıyla sağ kalım bakımından da en iyi sonuçları sağlar. Sirozlu hastalarda, HCC taraması ve takibi için alfa-fetoprotein (AFP) ve ultrasonografi (USG) kullanılmaktadır. Tanı çoğunlukla radyolojik yöntemlerle konulmaktadır; bilgisayarlı tomografi (BT) ve manyetik rezonans görüntüleme (MRG) ile kontrastlı multifazik incelemelerde kitlede, arteriyel fazda kontrast tutulumunda artış (enhacement) ve portal ya da geç venöz fazlarda ise temizlenme (washout) bulgularıyla karakterizedir (4). Tanıda radyolojik yöntemlerle netlik sağlanamaması halinde perkütan biyopsilerle histolojik değerlendirme de yapılabilmektedir (4).

Hepatorenal sendrom, renal dolaşım hacminin fonksiyonel azalması nedeniyle ortaya çıkan, hacim arttırılmasına (parenteral sıvı) yanıt vermeyen, sirozun en yaygın ve ciddi komplikasyonlarından biridir. İlerlemiş sirozu olan hastalarda ortaya çıkmakta olup, erken fark edilip hemen tedavi edilmezse yüksek mortaliteye sahiptir (5). Tarihsel olarak, HRS'nin iki alt tipi tanımlanmıştır. Tip 1 başlangıçta akuttur (iki haftadan az) ve kötü bir prognozun habercisidir. Tip 2 doğası gereği daha kroniktir ve diüretiklere dirençli refrakter asitlerle karakterize daha az şiddetli böbrek fonksiyon bozukluğu ile ilişkilidir. Uluslararası Asit Kulübü (ICA), 2015 yılında sirozlu hastalarda akut böbrek hasarının (AKI) önceki tanımlarını ve sınıflandırmalarını, Kidney Disease Improving Global
Outcomes (KIDGO) sınıflandırmasıyla uyumlu olarak güncellemiştir. Eski terim HRS Tip 1, HRS-AKI ile değiştirilmiştir. HRS-AKI kriterlerini karşılamayan sirotik hastalardaki fonksiyonel böbrek hasarı HRSNAKI (HRS-AKI olmayan) olarak adlandırılır ve serum kreatinini yerine tahmini glomerüler filtrasyon hızına (eGFR) dayanır (6). HRS-NAKI ayrıca iki alt tipe ayrılır; HRS- Akut Böbrek Hastalığı (HRS-AKD) ve HRSKronik Böbrek Hastalığı (HRS-CKD) (7). Hepatorenal sendrom bir dışlama tanısıdır ve bu konuda hala bazı tartışmalar olsa da karaciğer transplantasyonundan sonra geri dönüşümlü olması nedeniyle fonksiyonel bir patoloji olduğuna inanılmaktadır (8). Sistemik inflamasyon, HRS'nin patofizyolojisinde birincil rol oynar (8). Sistemik inflamasyon, bağırsaktan sistemik dolaşıma patolojik bakteriyel translokasyona neden olan bağırsak geçirgenliğindeki bir artışın bir sonucu olarak ortaya çıkar (9).

Sistemik inflamatuvar yanıtın (SIR) proinflamatuvar etkileri, meme kanseri (10), pankreas kanseri (11), kolorektal kanser (12) ve mide kanseri (13) gibi çeşitli kanserlerle ilişkilendirilmiştir. Kanser tarafından oluşturulan inflamatuvar yanıt, sitokinlerin ve inflamatuvar medyatörlerin upregülasyonu ile sonuçlanır, apoptozu inhibe ederek, anjiyogenezi teşvik ederek ve DNA'ya zarar vererek malignite eğiliminin artmasına neden olur. Nötrofil/lenfosit oranı (NLR), nötrofil/platelet oranı (NPR), sistemik immün inflamatuvar indeks (SII) ve CRP/albümin oranı (CAR) gibi inflamatuvar skorlar, çeşitli kanserlerde prognozu ve sağ kalımı tahmin etmede faydalı göstergeler olarak kabul edilmişlerdir. $\mathrm{Bu}$ indeksler arasında, NLR ve NPR, HCC'nin tedavi sonrası nüksünü ve sağ kalımını belirlemek için prognostik değerler olarak geniş çapta araştırılmıştır. Ancak, çalışma tasarımları ve örneklem büyüklüklerindeki farklılıklar nedeniyle bu çalışmalar tutarsız sonuçlar vermiştir. Bu nedenle NLR ve NPR'nin HCC'nin uygun prognostik göstergeleri olup olmadığı bilinmemektedir. Kanser dışında birçok hastalık ve modelde de serum biyobelirteçleriyle ilgili çalışmalar bulunmaktadır ancak HRS ile ilgili yeterli çalışma yoktur. Serum bazlı inflamatuvar skor ve indeksler, non-invaziv, hızlı, elde edilmesi kolay ve ucuz belirteçlerdir, bu nedenle yaygın klinik kullanım potansiyelleri olabilir.

Siroz hastalarında, HCC ve HRS varlığında serum biyobelirteçlerinin hem tanı konulması anlamında hem de sağ kalımı predikte etme bakımından etkinlik ve yeterlilikleri net bilinmemektedir. Bu çalışmada, serum biyobelirteçlerinin HCC ve HRS tanılı hastalarda tanı ve sağ kalım ilişkilerinin değerlendirilmesi ayrıca 
pratikte rutin kullanıma uygunluğun belirlenmesi amaçlanmıştır.

\section{HASTALAR VE YÖNTEM}

$\mathrm{Bu}$ çalışma, gözlemsel, retrospektif bir kohort çalışmasıdır. Gastroenteroloji ve Tıbbi Onkoloji kliniklerinde 2005 ve 2020 yılları arasında takip edilmiş hastaların verileri retrospektif taranmıştır. Çalışmaya 18 yaş üstü erişkin hastalar alınmıştır ve tüm hastalarda klinik ve laboratuvar olarak kesinleşmiş karaciğer sirozu tanısı mevcuttur. Kontrol grubu olarak sadece siroz tanılı olgular alınmıştır ve bu hastalarda HCC veya HRS tanıları yoktur. Kontrol grubuna ek olarak 3 ayrı grup daha tanımlanmıştır; HCC grubu, HRS grubu ve HCC\&HRS grubu. Kontrol grubuna malign hastalığı olanlar (HCC dışı) alınmamıştır. Çalışma için, Etik Kurulun 21.02.2020 tarihinde aldığı 2020/2318 sayılı kararla onay alınmıştır. İnsan katılımcıları içeren bu çalışmada gerçekleştirilen tüm prosedürler, kurumsal ve/veya ulusal araştırma komitesinin etik standartlarına ve 1964 Helsinki deklarasyonuna ve sonraki değişikliklere veya karşılaştırılabilir etik standartlara uygundur.

Tüm hastalarda siroz etiyolojisi, sağ kalım durumları, MELD (Model for End Stage Liver Disease) skoru, CTP (Child Turcotte Pugh) skoru, asit varlığı, ensefalopati varlığı, özofagus varis varlığı gibi demografik parametreler incelendi. Hastane otomasyon sisteminden hemogram, biyokimya testleri incelenerek serum biyobelirteç skorları elde edildi; ayrıca karaciğer ve böbrek fonksiyon testleri ve C-reaktif protein (CRP) düzeyleri de kayıt edildi.

\section{Biyobelirteçler}

Hemogram sonuçlarından elde edilen nötrofil, lenfosit ve platelet sayımları kullanılarak tüm hasta grupları için, nötrofil-lenfosit oranı (NLR), nötrofilplatelet oranı (NPR) skorları saptandı. Sistemik immün inflamatuvar indeks (SII) skoru, SII= Platelet $x$ NLR formülüyle hesaplandı. CRP'nin albümine oranı (CAR) olan biyobelirteç skoru CAR= CRP/Albümin formülüyle hesaplandı. Çalışmaya dahil edilmiş tüm hastalarda tüm indeksler eksiksiz hesaplandı.

\section{Tanı kriterleri}

Uluslararası Asit Kulübü (ICA) HRS tanı kriterlerini karşılayan hastalar çalışmaya dahil edildiler; verilerine ulaşılabilen hastalarda eGFR değerleri de göz önünde bulunduruldu. Hepatorenal sendrom tanılı olguların ayrıca Tip 1 ve 2 olarak alt tiplendirmeleri de yapıldı. Renal hastalık bulgusu olan ya da kriterleri tam karşılamayan hastalar çalışmaya dahil edilmedi. Hepatoselüler karsinom tanısı radyolojik ve/veya histolojik yöntemlerle konulmuş hastalar çalışmaya dahil edildi. Radyolojik olarak hem BT hem de MRG tetkikleri incelendi; arteriyel fazda kontrast tutulumunda artış (enhacement) ve portal ya da geç venöz fazlarda ise temizlenme (washout) bulgularını karşılayan olgular dahil edildi. Hastalara ait verilere hastane otomasyon sistemi üzerinden ulaşıldı ancak eksik bilgilerin temini için gereğinde hasta dosyaları da tarandı ve incelendi. Sağ kalım verileri için hastaların toplam takip süreleri kayıt edilmiştir. Toplam takip süresi, ilk tanı tarihi ile son başvuru tarihi veya ölüm tarihi arasındaki süre (gün) olarak kabul edilmiştir. Çalışmanın sonlanım noktası olarak hastanın ölümü ve hastaneye son başvuru tarihi kabul edilmiştir. Çalışmanın sonlandığı tarihte dosya kayıtları, hastane otomasyon sisteminden ve merkezi nüfus idare sisteminden hastaların hayatta olup olmadığı araştırıldı.

\section{İstatiksel analiz}

Analizler, SPSS versiyon 25 ve MedCalc versiyon 15.8 yazılımları kullanılarak yapıldı. Değişkenlerin normal dağılıma uygunluğu görsel (histogram ve olasılık grafikleri) ve analitik yöntemler (KolmogorovSmirnov/Shapiro-Wilk testleri) kullanılarak incelenmiştir. Normal dağılmayan değişkenler için ortanca ve çeyrekler arası aralıklar kullanılarak tanımlayıcı analizler verildi. Değişkenler normal dağılmadığı için gruplar arasında Kruskal-Wallis testi kullanılarak karşılaştırma yapıldı. En az biri normal dağılmayan veya sıralı olmayan değişkenler arasındaki ilişkiler için Spearman testi ile korelasyon katsayıları ve istatistiksel anlamlılık hesaplandı.

Serum biyobelirteç değerlerinin, HCC ve HRS tahmin etmede tanısal karar verme özellikleri, Receiver Operating Characteristics (ROC) analizi ile incelendi. Youden indeksi ile elde edilen eşik değerlerine göre duyarlılık, özgüllük, pozitif prediktif ve negatif prediktif değerleri hesaplandı. Serum biyobelirteçlerinin genel sağ kalım eğrileri Kaplan-Meier yöntemiyle çizildi ve log rank testi kullanılarak karşılaştırıldı. Çok değişkenli analizde, önceki analizlerde belirlenen olası faktörler kullanılarak sağ kalımı öngörmedeki bağımsız etkenler geriye doğru (backward) seçim yöntemi ile Cox regresyon analizi kullanılarak incelendi. Sağ kalım üzerine benzer etki gösteren birbiri ile ilişkili parametrelerden modele klinik açıdan anlamlı olanlar seçildi. Model uyumu ve dönemsel riskin oransallığı varsayımları rezidüel (Schoenfeld ve Martingale) analizleri kullanılarak değerlendirildi.

Çalışmada tüm testlerde istatistiksel anlamlılık için p değerinin 0,05 'in altında olduğu durumlar istatistiksel 
Table 1. Hastaların klinik, demografik ve laboratuvar parametrelerinin karşılaştırmaları.

\begin{tabular}{|c|c|c|c|c|c|}
\hline Toplam $n=110$ & $\operatorname{HCC}(n=27)$ & HRS ( $n=18)$ & HCC\&HRS $(n=36)$ & SiROZ (n=29) & $\mathbf{P}$ \\
\hline$\overline{\text { Yaş }}$ & $67,56 \pm 1,94^{a}$ & $67,22 \pm 1,76^{\mathrm{a}, \mathrm{b}}$ & $68,36 \pm 1,5^{a}$ & $61,17 \pm 2,1^{\mathrm{b}}$ & 0,074 \\
\hline MELD & $14(9-22)^{a}$ & $25,5(20,7-31,2)^{b}$ & $33,5(32-39,7)^{b}$ & $15(11-19)^{a}$ & $<0,001$ \\
\hline CHILD & $8(7-11)^{a}$ & $12(10-13,25)^{b}$ & $12(11-13,75)^{b}$ & $9(7-10,5)^{a}$ & $<0,001$ \\
\hline Sağ kalım süresi & $540(180-1110)^{a}$ & $95(12,5-180)^{b}$ & $131(39,25-475)^{\mathrm{b}}$ & $180(150-180)^{b}$ & $<0,001$ \\
\hline NLR & $3,33(2,34-6,67)^{\mathrm{a}}$ & $4,97(3,04-11,65)^{a, b}$ & $9,99(5,63-20,55)^{\mathrm{b}}$ & $2,8(1,98-4,54)^{a}$ & $<0,001$ \\
\hline NPR & $0,03(0,02-0,04)^{a}$ & $0,04(0,03-0,07)^{a, b}$ & $0,08(0,04-0,17)^{\mathrm{b}}$ & $0,03(0,02-0,04)^{a}$ & $<0,001$ \\
\hline SII & $527(291-1246)^{a, b}$ & $416(254-901)^{a, b}$ & $1129(540-2594)^{a}$ & $369(174-605)^{b}$ & $<0,001$ \\
\hline CAR & $7,33(2,06-15,18)^{a}$ & $12,24(9,26-14,71)^{a, b}$ & $17,53(10,82-32,53)^{b}$ & $8(3,89-11,08)^{a}$ & $<0,001$ \\
\hline Hemoglobin & $12,5(10,7-13,7) a$ & $8,8(8,2-10,2)^{b}$ & $10,7(8,9-11,9)^{\mathrm{b}}$ & $11,4(9,8-12,7)^{a}$ & $<0,001$ \\
\hline Lökosit & $7000(4850-9560)^{a}$ & $6290(5300-8527)^{a}$ & $12570(7427-17990)^{\mathrm{b}}$ & $5520(3770-7670)^{a}$ & $<0,001$ \\
\hline Nötrofil & $4450(2790-6910)^{a}$ & $4400(3427-6245)^{a}$ & $10230(5682-15075)^{b}$ & $3790(2050-5325)^{a}$ & $<0,001$ \\
\hline Lenfosit & $1180(750-1690)^{a}$ & $920(350-1450)^{a}$ & $935(500-1500)^{a}$ & $1200(715-1500)^{a}$ & 0,41 \\
\hline Platelet & $124(85-185)^{\mathrm{a}}$ & $94,5(78,5-111)^{a}$ & $104(52,2-175)^{a}$ & $114(80-175)^{a}$ & 0,26 \\
\hline INR & $1,34(1,19-1,8)^{a}$ & $2,07(1,53-2,43)^{b, c}$ & $2,33(1,55-3,16)^{b}$ & $1,61(1,33-1,91)^{a, c}$ & $<0,001$ \\
\hline AST & $62(34-168)^{a}$ & $51(46-80,7)^{a}$ & $211,5(96,5-578,5)^{b}$ & $49(35,5-98)^{a}$ & $<0,001$ \\
\hline ALT & $29,2(21,9-82)^{a, c}$ & $30(18-59)^{a, b}$ & $94(34-304,5)^{\mathrm{c}}$ & $24(18-44)^{a}$ & $<0,001$ \\
\hline Albümin & $2,9(2,6-3,6)^{a}$ & $2,4(2,1-2,85)^{b}$ & $2,7(2,4-2,9)^{a, b}$ & $2,9(2,6-3,35)^{a}$ & 0,003 \\
\hline T. Bilirubin & $1,83(1-7,01)^{a}$ & $2,8(1,75-10,17)^{a}$ & $14,83(6,59-28,98)^{b}$ & $1,7(1,05-3,45)^{a}$ & $<0,001$ \\
\hline D. Bilirubin & $0,74(0,3-4,64)^{a}$ & $1,18(0,67-4,77)^{a}$ & $8,82(4,44-20,38)^{b}$ & $0,5(0,2-1,05)^{a}$ & $<0,001$ \\
\hline CRP & $20,63(6,06-41)^{a}$ & $26,5(18,52-37,2)^{a}$ & $44,65(28,52-77,75)^{b}$ & $22,6(11,8-32,65)^{a}$ & $<0,001$ \\
\hline Kreatinin & $0,78(0,64-0,88)^{a}$ & $2,19(1,86-2,52)^{b}$ & $2,54(1,81-3,15)^{b}$ & $0,8(0,7-1,12)^{a}$ & $<0,001$ \\
\hline
\end{tabular}

HCC: Hepatoselüler karsinom; HRS: Hepatorenal sendrom; Gruplar arası karşılaştırmalar Kruskall Wallis testiyle yapılmıştır.

olarak anlamlı sonuç olarak kabul edilmiştir.

\section{BULGULAR}

Çalışmaya toplam 110 hasta alınmıştır; hastaların 26 'sı $(\% 23,6)$ kadın iken 84 'ü $(\% 76,4)$ erkektir. Siroz grubunda $29(\% 26,4)$ hasta, HCC grubunda 27 (\%24,5), HRS grubunda $18(\% 16,4)$ ve HCC\&HRS grubunda ise $36(\% 32,7)$ hasta vardır. Gruplardan bağımsız olarak tüm popülasyonda hastaların 63'ü $(\% 57,3)$ HCC iken 54'ü $(\% 49,1)$ HRS tanılıdır; HRS hastalarında $36(\% 32,7)$ Tip 1 ve $18(\% 16,4)$ ise Tip 2 hastasıdır. Hastaların 12'si $(\% 10,9)$ CHILD A, 29'u $(\% 26,4)$ CHILD B iken 69'u $(\% 62,7)$ CHILD C idi. Gruplara göre MELD skoru dağılımları ise, siroz grubunda 15 (11-19), HCC grubunda 14 (7,8-22), HRS grubunda $25,5(20,7-31,2)$ ve HCC\&HRS grubunda ise $33,5(32-39,7)$ saptandı.

Siroz etiyolojisi bakımından $62(\% 56,4)$ hastada HBV, 15 (\%13,6) HCV, 19 (\%17,3) kriptojenik iken 14 $(\% 12,7)$ diğer etiyolojiler yer almaktaydı. Hastaların
84 'de $(\% 76,4)$ asit saptandı; 16 hafif, 15 orta ve 53 hastada gergin (tense) asit vardı. Yine tüm hastaların 41 'de $(\% 37,3)$ ensefalopati öyküsü saptandı. Gruptan bağımsız olarak $86(\% 78,2)$ hastada özofagus varisleri vardı; 29 grade I, 31 grade II ve 26 grade III. Hastaların gruplara göre klinik, demografik, laboratuvar parametrelerinin ve biyobelirteçlerin karşılaştırmaları Tablo 1'de gösterilmiştir. Sağ kalım bakımından değerlendirmede takip sürecinde tüm hastaların 68'i $(\% 61,8)$ kaybedilmiştir (exitus); 27 (tüm hastaların \%24,5'i) hasta ilk 1 yıl içinde kaybedilmiştir. Tip 1 HRS hastalarının ortanca kreatinin değeri 2,7 $(2,12-3,16)$ iken Tip 2 HRS hastalarının ise 1,92 (1,6$2,2)$ saptandı; $p<0,001$. Ayrıca Tip 1 HRS hastalarında ortanca MELD 33,5 (30,3-39) ve Tip 2'lerde ise 26,5 $(22,3-33,5)$ hesaplanmıştır; $p=0,003$.

Spearman's rho korelasyon analizlerinde tüm biyobelirteçler (NLR, NPR, SIl ve CAR) ve sağ kalım, HRS ve HCC tanıları arasında zayıf korelasyonlar $(r<0,5$ ve $p<0,001)$ saptanmıştır.

Tablo 2. Biyobelirteçlerin, Hepatorenal Sendrom tespit etme yeteneklerinin ROC analizleriyle karşılaştırmaları.

\begin{tabular}{llllllll}
\hline & Eşik & AUC (95\% GA) & Sens. \% & Spes. $\%$ & PPV \% & NPV \% & P \\
\hline NLR & $>5,161$ & $0,774(0,684-0,848)$ & 70,37 & 78,57 & 76,66 & 72,62 & 70 \\
NPR & $>0,046$ & $0,777(0,688-0,851)$ & 64,81 & 82,14 & 73,40 & $<0,001$ \\
SII & $>624$ & $0,674(0,578-0,760)$ & 62,96 & 73,21 & 70,15 & 66,40 \\
CAR & $>11,25$ & $0,740(0,647-0,819)$ & 72,22 & 71,43 & 71,65 & 72 & $<0,001$ \\
\hline
\end{tabular}

CAR: CRP-albümin oranı; NLR: Nötrofil lenfosit oranı; NPR: Nötrofil platelet oranı; SII: Sistemik immün inflamatuvar indeks; AUC: Eğri altındaki alan; GA: Güven aralığı; Sens: Sensitivite; Spes: Spesifisite; PPV: Pozitif prediktif değer; NPV: Negatif prediktif değer. 
Tablo 3. Biyobelirteçlerin, tanı gruplarından bağımsız genel sağ kalım tahmin etme yeteneklerinin ROC analizleriyle karşılaştırmaları.

\begin{tabular}{llllllll}
\hline & Eşik & AUC (95\% GA) & Sens. $\%$ & Spes. $\%$ & PPV $\%$ & NPV \% & P \\
\hline NLR & $>4,615$ & $0,770(0,680-0,845)$ & 70,59 & 80,95 & 78,75 & 73,35 \\
NPR & $>0,046$ & $0,734(0,641-0,813)$ & 57,35 & 85,71 & 80,05 & 66,77 \\
SII & $>667$ & $0,721(0,628-0,803)$ & 58,82 & 80,95 & 75,54 & 66,28 \\
CAR & $>10,92$ & $0,776(0,687-0,850)$ & 70,59 & 80,95 & 78,75 & 73,35 \\
\hline
\end{tabular}

CAR: CRP-albümin oranı; NLR: Nötrofil lenfosit oranı; NPR: Nötrofil platelet oranı; SII: Sistemik immün inflamatuvar indeks; AUC: Eğri altındaki alan; GA Güven aralığı; Sens: Sensitivite; Spes: Spesifisite; PPV: Pozitif prediktif değer; NPV: Negatif prediktif değer.

Serum biyobelirteçlerin, Hepatorenal Sendrom tespit etme yeteneklerinin ROC analizleriyle karşılaştırmalarında AUC değeri 0,7 üzerinde saptanmayan tek biyobelirteç SIl'dır; >624 eşik değeri için AUC: 0,674 (0,578 - 0,760), Tablo 2 ve Şekil 1. Biyobelirteçlerin HCC tespit etme yeteneklerinin ROC analiziyle karşılaştırılmasında ise tüm biyobelirteçler için AUC<0,7 saptanmıştır; Şekil 2.

Serum biyobelirteçlerin, tanı gruplarından bağımsız genel sağ kalımı tahmin etme yeteneklerinin ROC analizleriyle karşılaştırmalarında tüm biyobelirteçler için AUC $>0,7$ saptanmıştır (Tablo 3); en yüksek sensitivite $(\% 70,59)$ ve spesifisite $(\% 80,95)$ değerleri NLR ve CAR için saptanmıştır. Tüm biyobelirteçler için sağ kalım eğrileri (Kaplan-Meier) Şekil 3-6'de gösterilmiştir. Sağ kalım analizlerinde, NLR>4,615

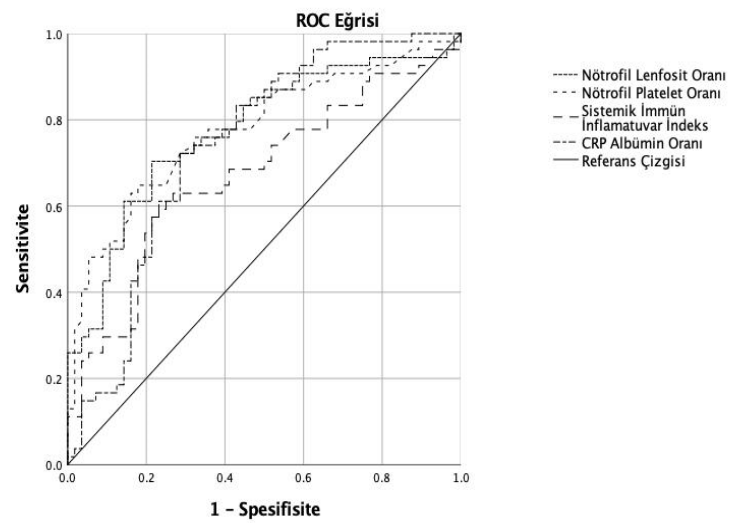

Şekil 1. Biyobelirteçlerin HRS tespit etme yeteneklerinin ROC analiziyle karşılaştırılması. NLR AUC: 0,774 (0,685 $0,863), p<0,001$; NPR AUC: $0,777(0,689-0,865), p<0,001$; SII AUC: $0,674(0,572-0,776), p=0,002$; CAR AUC: 0,740 $(0,646-0,834), p<0,001$.

AUC: Eğri altındaki alan; NLR: Nötrofil lenfosit oranı; NPR: Nötrofil platelet oranı; SII: Sistemik immün inflamatuvar indeks; CAR: CRP albümin oranı. değeri için HRS grubunda $(p=0,026)$ ve Siroz grubunda $(p<0,001) ; \quad S I l>667$ değeri için HRS grubunda $(p=0,005) ; C A R>10,92$ değeri için HCC grubunda $(p=0,034)$, HRS grubunda $(p=0,023)$ ve HCC\&HRS grubunda $(p<0,001)$ prediktif bulunmuştur.

Univariate ve Multivariate Cox Regresyon analizleriyle, backward stepwise metoduyla, biyobelirteçlerin sağ kalımı bağımsız predikte etme yetilerinin incelenmesinde modele tüm biyobelirteçler dahil edildiğinde model, 3. aşamada NPR ve CAR ile (sırasıyla $p=0,021$ ve $p<0,001$ ) tamamlanmıştır (Tablo 4); $\operatorname{Exp}(B)$ değerleri NPR için 1,790 (1,094 - 2,929) ve CAR için 2,944 (1,724 - 5,029) saptanmıştır.

\section{TARTIŞMA}

Serum biyobelirteçlerinin siroz hastalarında, HCC

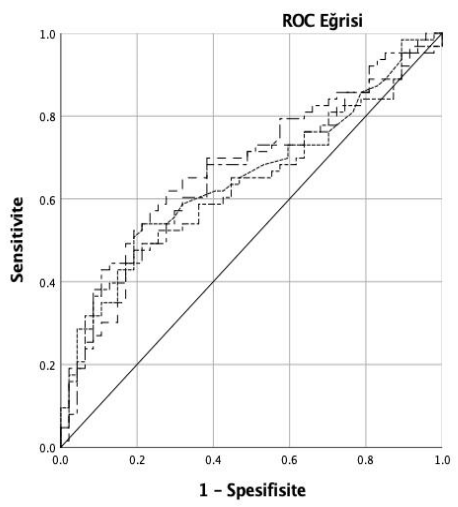

- - Nötrofil Lenfosit Oran
---- Nötrofil Platelet Oran
Sistemik Immün - CRP Albümin Oran Referans Çizgisi
Şekil 2. Biyobelirteçlerin HCC tespit etme yeteneklerinin ROC analiziyle karşılaştırılması. NLR AUC: 0,664 (0,562 $0,766), p=0,003$; NPR AUC: $0,650(0,548-0,752), p=0,007$; SII AUC: $0,670(0,569-0,771), p=0,002$; CAR AUC: 0,634 $(0,531-0,738), p=0,016$.

AUC: Eğri altındaki alan; NLR: Nötrofil lenfosit oranı; NPR: Nötrofil platelet oranı; SII: Sistemik immün inflamatuvar indeks; CAR: CRP albümin oranı. 
Tablo 4. Biyobelirteçlerin sağ kalıma katkılarının Univariate ve Multivariate Cox Regresyon analiziyle incelenmesi (backward stepwise yöntemiyle).

\begin{tabular}{lllll}
\hline & P & Univariate & Multivariate \\
NLR $(\leq 4,615$ vs $>4,615)$ & 0,001 & $2,422(1,429-4,103)$ & P & \\
NPR $(\leq 0,046$ vs $>0,046)$ & 0,001 & $2,254(1,391-3,654)$ & 0,021 & $1,790(1,094-2,929)$ \\
SII $(\leq 667$ vs $>667)$ & 0,005 & $2,012(1,238--3,269)$ & & \\
CAR $(\leq 10,92$ vs $>10,92)$ & $<0,001$ & $3,343(1,980-5,646)$ & $<0,001$ & $2,944(1,724-5,029)$ \\
\hline
\end{tabular}

CAR: CRP-albümin oranı; NLR: Nötrofil lenfosit oranı; NPR: Nötrofil platelet oranı; SII: Sistemik immün inflamatuvar indeks; GA: Güven aralığı. Model: NLR, NPR, SII ve CAR; model 3. aşamada NPR ve CAR ile tamamlanmıştır.

ve HRS ile ilişkilerinin değerlendirildiği bu çalışmada tüm biyobelirteç skorları, gruplar arasında anlamlı farkılık göstermekle birlikte sağ kalım bakımından gruplardan bağımsız olarak prediktif değere sahiptirler. Ayrıca SII hariç diğer tüm biyobelirteçler, HRS tespit etme bakımından prediktif değere sahiptir. Gruplara göre kıyaslama yapıldığında ise CAR skorları, sağ kalım bakımından HCC, HRS ve HCC\&HRS gruplarında prediktif değere sahiptir.

Çalışma hastalarının yaşları arasında anlamlı fark olmamasına karşın cinsiyet bakımından erkek cinsiyet baskındır; retrospektif çalışma olması nedeniyle bu denge sağlanamamıştır. Gruplar arasında, MELD skorları en yüksek değerlerine HRS ve HCC\&HRS gruplarında ulaşmaktadır ve bu durum, kısa vadede HRS hastalarının hem transplantasyon hem de sağ kalım bakımından daha öncelikli değerlendirilmeleri gerekliliğini doğrulamaktadır. Sağ kalım sürelerine baktığımızda, en uzun sağ kalım süresi HCC grubundayken en kısa süre ise HRS grubunda görünmektedir. Muhtemelen radyolojik ablatif tedaviler (Radyofrekans Ablasyon (RF) ve Transarteriyel

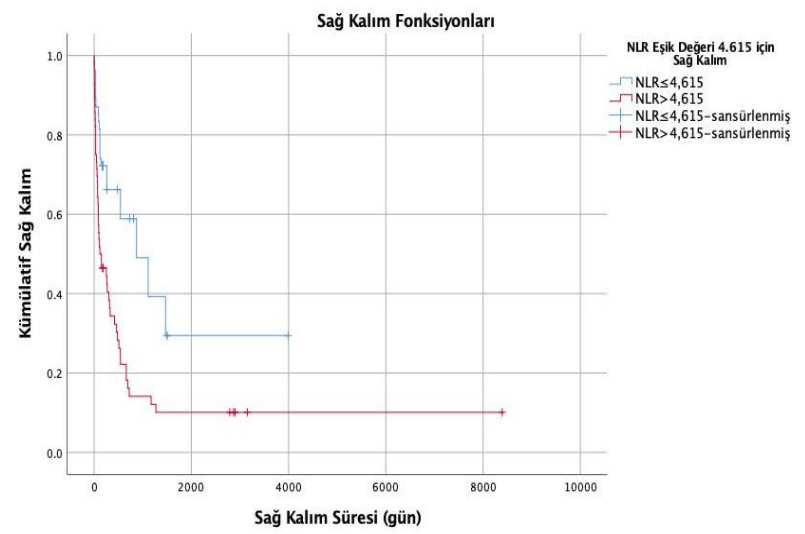

Şekil 3. NLR için eşik değer 4,615 iken sağ kalım eğrisi. Kaplan-Meier eğrisi; $x 2=11,707, p=0,001$.
Kemoembolizasyon (TACE) tedavileri gibi), cerrahi rezeksiyonlar ve karaciğer transplantasyonları HCC hastalarında sağ kalımı artırmakta ancak HRS hastalarında ise sağ kalımı artıracak hâlâ yeni bir tedavi modalitesi bulunamaması ve transplantasyon hazırlığında da gecikmeler nedeniyle hasta kaybının fazla olması bu durumu açıklamaktadır. Tüm gruplarda SII hariç en yüksek biyobelirteç skorlarının HCC\&HRS ve ardından HRS gruplarında olması hem klinik prognoz hem de sağ kalım bakımından dominant belirleyici faktörün HRS olduğunu ve dolayısıyla altta yatan neden olarak portal hipertansiyonun önemini ortaya koymaktadır. Transplantasyon önceliğini predikte etmede kullandığımız MELD skoru HRS hastalarında ek bir ayrıcalık ya da öncelik farkındalığı veremediğinden ek prediktif belirleyici parametrelere intiyaç vardır. Serum biyobelirteçleri bu anlamda bu prediktif değerlendirmeyi sağlayabilirler; NLR, PLR ve CAR skorlarının kombin değerlendirmeyle bu grupta katkısı daha etkin olacaktır.

Gruplar arası lenfosit değerlerinin benzer olması ancak hem NLR hem de NPR değerlerinde ise

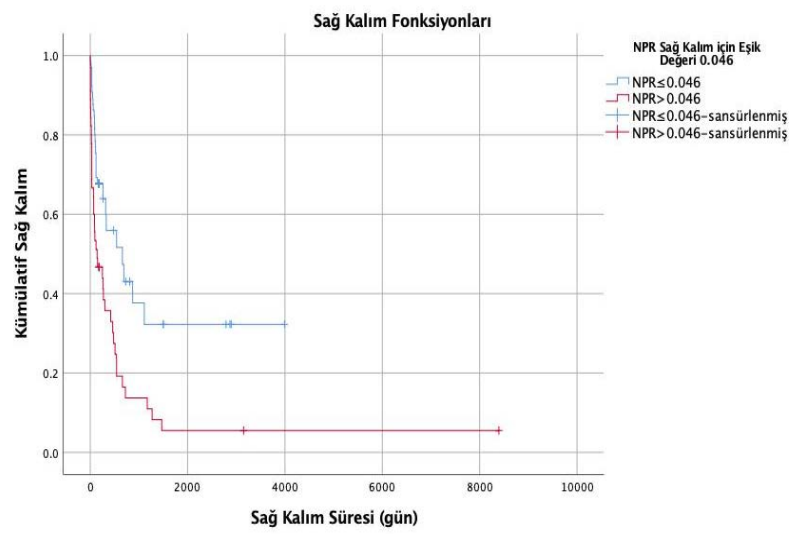

Şekil 4. NPR için eşik değer 0,046 iken sağ kalım eğrisi. Kaplan-Meier eğrisi; $x 2=11,687, p=0,001$. 


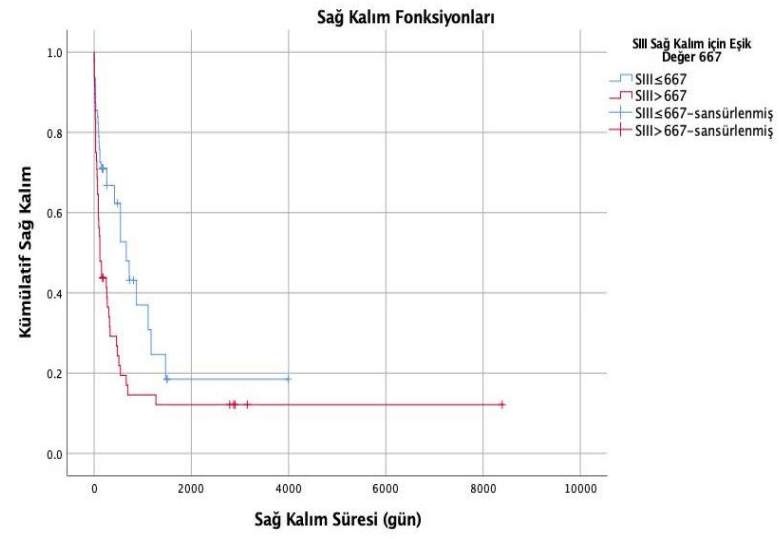

Şekil 5. SII için eşik değer 667 iken sağ kalım eğrisi. Kaplan-Meier eğrisi; $x 2=8,432, p=0,004$.

anlamlı farkların saptanması biyobelirteçlerin prediktif etkilerinin nötrofil ve platelet dağılımlarından kaynaklandığını göstermektedir. Esasen NLR'nin çıkış noktası olarak, nötrofil düzeyindeki artışın inflamasyona bağlı olduğu ve lenfosit sayısındaki azalmanın ise malnütrisyona sekonder olduğu ifade edilmiştir $(14,15)$. Dolayısıyla hem HCC hem de HRS hastalarında malnütrisyon ve kronik inflamasyon varlığı, biyobelirteçlerin bu gruplarda farklı eşik değerlerde skorlar elde edilebilmelerine ve böylece, sağ kalım ve hastalığı tespit etme imkânı vermektedir. $\mathrm{Bu}$ çalışmada da nötrofil sayılarının en yüksek olduğu grup HCC\&HRS hastalarıdır. Platelet değeri istatiksel anlamlı düzeyde en düşük saptanan grup ise HRS hastalarıdır ve bu durum beklendiği üzere bu hastalarda diğerlerine nispeten artmış portal basıncın sonucudur.

Biyobelirteçlerin (SII hariç) HRS tespit etme gücü anlamlı düzeyde saptanmasına karşın HCC tespitinde başarılı saptanmamıştır. Biyobelirteçler inflamasyon odaklı yükseldiğinden ve HRS hastalarında inflamasyon HCC hastalarına nispeten daha belirgin olduğundan bu durumun ortaya çıktığı kanaatindeyiz. Biyobelirteçlerden SII, formülü gereği platelet sayısı arttıkça daha yüksek skorlar verdiğinden ve en düşük platelet düzeyi de HRS hastalarında saptandığından HRS tespit etmede yetersiz kalmaktadır.

Sağ kalım analizlerinde en yüksek prediktif değerler NLR ve CAR biyobelirteçleri ile elde edilmesine karşın Cox regresyon modelinde NPR ve CAR biyobelirteçleri tek başlarına prediktif değere sahip bulunmuştur. Literatürde NPR biyobelirteciyle ilgili yapılmış az sayıda çalışma bulunmaktadır. Yamamoto-Furusho

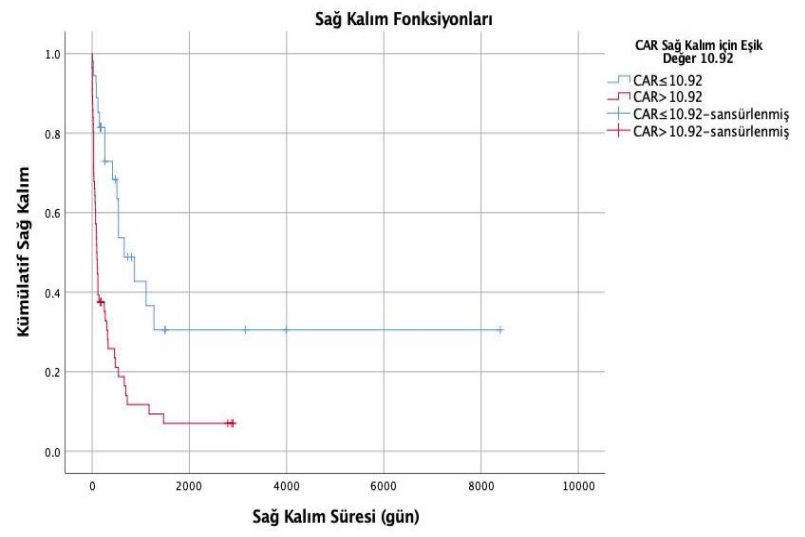

Şekil 6. CAR için eşik değer 10,92 iken sağ kalım eğrisi. Kaplan-Meier eğrisi; $x 2=23,337, p<0,001$.

et al. (16) NPR'i, ülseratif kolit hastalarında yeterli bir tanısal araç olarak bildirmişlerdir. He et al. (17) ise yüksek NPR değerlerinin akut iskemik inmeli olgularda yüksek hipertansiyonla ilişkili olduğunu göstermişlerdir. Bizim çalışmamızda, NPR'nin $\mathrm{HCC}$ ve HRS hastalarında prediktif saptanması, bu hastalarda portal hipertansiyona bağlı hemodinamik değişikliklerin doğrudan platelet ve nötrofil dengesine etkide bulunmasından kaynaklandığını düşündürmektedir. Sağ kalımı predikte etmede NPR başarılı iken HCC tespit etmede yetersiz ancak HRS tespit etmede ise yeterli saptanmıştır; bu durum portal hipertansiyon savını doğrulamaktadır.

Literatürde HCC ve NLR ilişkisiyle ilgili çok sayıda çalışmalar bulunmaktadır; sağ kalım, tanısal, transplantasyon ve takip çalışmaları gibi. Wang et al. (18), NLR'nin TACE ile tedavi edilen HCC hastalarında genel sağ kalım ile önemli ölçüde ilişkili olduğunu, hasta seçimi ve prognostik tahminde faydalı olabileceğini belirtmişlerdir. Mouchli et al. (19) ise NLR, güvenilir ve ucuz bir biyobelirteçtir ve HCC tedavisini takiben sonuçların belirlenmesine yardımcı olmak için diğer prognostik modellere dahil edilmelidir şeklinde bir çıkarımda bulunmuşlardır. Literatürde HRS ile ilgili yeterli NLR çalışması bulunamamıştır. Bizim çalışmamızda NLR, HCC tespitinde yetersiz saptanmıştır; AUC: 0,664 \%95 GA 0,568-0,752. Diğer taraftan NLR, HRS tespitinde ise oldukça yeterlidir. Ayrıca NLR, sağ kalımı predikte etmede de yeterli saptanmıştır.

Hu et al. (20) SIl'i, HCC'li hastalarda kötü sonucun güçlü bir prognostik göstergesi ve HCC tedavi stratejisi kararları için umut verici bir araç olarak 
tanımlamışlardır. Yakın zamanda yayınlanmış bir meta-analizde ise yüksek SII, HCC'li hastalar için kötü bir prognostik faktördür ve SII'nin klinik uygulaması, HCC'nin progresyonunu değerlendirmek için teşvik edilebilir şeklinde yorumlanmıştır. Hepatorenal sendrom hastalarında SIl ilişkisini değerlendiren bir çalışma bulunamamıştır. Bizim çalışmamızda ise SII skoru en yüksek HCC\&HRS grubunda saptanmakla birlikte genel sağ kalımı predikte etmeye yeterli bulunmuştur ancak tanısal değeri yeterli bulunamamıştır. Klinik uygulamada diğer biyobelirteçlere nazaran kullanılabilirliği kısıtlıdır.

Yakın zamanda, Liao et al. (21) derleme yazılarında, tedaviöncesi yüksek CAR skorları, kolorektal kanserde kötü genel sağ kalım, hastalıksız sağ kalım ve progresyonsuz sağ kalım ile ilişkilendirilmiş ve ayrıca klinik uygulamada kolorektal kanser için prognostik bir belirteç olarak kullanılabileceği iddia edilmiştir. Preoperatif CAR, HCC'li hastalarda küratif rezeksiyon sonrası tümörsüz sağ kalımı belirlemede bağımsız bir prognostik belirteçtir ve prognostik yeteneği, diğer inflamasyona dayalı prognostik biyobelirteçlerle karşılaştırılabilir (22). Bizim çalışmamızda, en yüksek CAR skoru HCC\&HRS grubunda saptanmakla birlikte CAR, HRS tespit etmede ve genel sağ kalımı predikte etmede oldukça yeterli saptanmıştır. Cox regresyon analizinde de sağ kalım bakımından bağımsız prediktör bulunmuştur.

Serum biyobelirteçleri, non-invaziv olmaları, düşük maliyet, kolay uygulanabilir olma, hızlı sonuç alabilme gibi avantajları nedeniyle çok çalışmalar yapılmış ve yüksek oranda olumlu sonuçlar elde edilmiş diagnostik ve prognostik skorlama sistemleridir. Literatürde her ne kadar HCC ve sirozla ilgili çok yayın bulunsa da HRS ile ilgili çalışmalar ve veriler yetersizdir. Bu bakımından çalışmamız hem bu anlamda değer katmakta hem de bilinen bu biyobelirteçlerin kombin olarak bu hasta grubunda kullanıldıklarında ortaya çıkan etki ve sonuçlarını belirlemek bakımından kıymetlidir. Diğer yandan her ne kadar istatiksel anlamda olumlu sonuçlar elde ediliyor olsa da çoğu hastalıkta inflamasyon ve malnütrisyon eşlik ettiğinden, spesifisite yetersizliği nedeniyle rutin klinik uygulamada halen daha etkin kullanılamamaktadırlar. Çalışmadaki HRS hasta sayısının diğer gruplara nispeten daha az olması göreceli olarak bir dezavantaj sayılabilir ancak bu çalışmada en yüksek hasta sayısı da HCC\&HRS grubundadır ve dolayısıyla HRS ve biyobelirteçlerin ilişkisi bakımından bir zafiyet olmadığı kanaatindeyiz.

Sonuç olarak, NLR, NPR, SII ve CAR serum biyobelirteçleri siroz hastalarında HCC, HRS varlığında genel sağ kalımı predikte etmeye yeterlidirler. Hepatorenal sendromu tespit etme bakımından NLR, NPR ve CAR yeterli sensitivite ve spesifisiteye sahiptir. Klinik uygulamada kullanılabilirliklerini belirlemek bakımından geniş hasta popülasyonlarında, özellikle hepatorenal sendromlu olgularda çalışmalar yapılması daha net ve güvenilir sonuçlar verecektir.

Çıkar Çatışması: Çalışmada herhangi bir çıkar çatışması yoktur.

Finansal Çıkar Çatışması: Çalışmada herhangi bir finansal çıkar çatışması yoktur.

Yazışma Adresi: Muharrem Keskin, Necmettin Erbakan Üniversitesi, Meram Tıp Fakültesi, Gastroenteroloji BD, Konya, Türkiye

Phone: +905552242474

E-mail: mkeskin@erbakan.edu.tr

\section{KAYNAKLAR}

1. Fitzmaurice C, Allen C, Barber RM, et al. Global burden of disease cancer c global, Regional, and national cancer incidence, mortality, years of life lost, years lived with disability, and disability-adjusted life-years for 32 cancer groups, 1990 to 2015: A systematic analysis for the global burden of disease study. JAMA Oncol 2017;3(4):524-48.

2. Yang JD, Harmsen WS, Slettedahl SW, et al. Factors that affect risk for hepatocellular carcinoma and effects of surveillance. Clin Gastroenterol Hepatol 2011;9(7):617-23 e1.

3. Yang JD, Kim WR, Park KW, et al. Model to estimate survival in ambulatory patients with hepatocellular carcinoma. Hepatology 2012;56(2):614-21.

4. Marrero JA, Kulik LM, Sirlin CB, et al. Diagnosis, staging, and management of hepatocellular carcinoma: 2018 Practice Guidance by the American Association for the Study of Liver Diseases. Hepatology 2018;68(2):723-50.

5. Russ KB, Stevens TM, Singal AK. Acute kidney injury in patients with Cirrhosis. J Clin Transl Hepatol 2015;3(3):195204.

6. Angeli P, Gines P, Wong F, et al. Diagnosis and management of acute kidney injury in patients with cirrhosis: Revised consensus recommendations of the International Club of Ascites. J Hepatol 2015;62(4):968-74.

7. National Kidney F. K/DOQI clinical practice guidelines for chronic kidney disease: Evaluation, classification, and stratification. Am J Kidney Dis. 2002;39(2 Suppl 1):S1-266.

8. Busk TM, Bendtsen F, Moller S. Hepatorenal syndrome in cirrhosis: Diagnostic, pathophysiological, and therapeutic aspects. Expert Rev Gastroenterol Hepatol 2016;10(10):115361.

9. Wiest $R$, Lawson $M$, Geuking $M$. Pathological bacterial translocation in liver cirrhosis. J Hepatol 2014;60(1):197-209.

10. Koh $\mathrm{CH}$, Bhoo-Pathy $\mathrm{N}, \mathrm{Ng} \mathrm{KL}$, et al. Utility of pre-treatment neutrophil-lymphocyte ratio and platelet-lymphocyte ratio as prognostic factors in breast cancer. $\mathrm{Br} \mathrm{J}$ Cancer 2015;113(1):150-8.

11. Smith RA, Bosonnet $L$, Raraty $M$, et al. Preoperative plateletlymphocyte ratio is an independent significant prognostic 
marker in resected pancreatic ductal adenocarcinoma. Am J Surg 2009;197(4):466-72.

12. Kwon HC, Kim SH, Oh SY, et al. Clinical significance of preoperative neutrophil-lymphocyte versus plateletlymphocyte ratio in patients with operable colorectal cancer. Biomarkers 2012;17(3):216-22.

13. Aliustaoglu M, Bilici A, Ustaalioglu BB, et al. The effect of peripheral blood values on prognosis of patients with locally advanced gastric cancer before treatment. Med Oncol 2010;27(4):1060-5.

14. Avanzas P, Quiles J, Lopez de Sa E, et al. Neutrophil count and infarct size in patients with acute myocardial infarction. Int J Cardiol 2004;97(1):155-6.

15. Fock RA, Blatt SL, Beutler B, et al. Study of lymphocyte subpopulations in bone marrow in a model of protein-energy malnutrition. Nutrition 2010;26(10):1021-8.

16. Yamamoto-Furusho JK, Mendieta-Escalante EA. Diagnostic utility of the neutrophil-platelet ratio as a novel marker of activity in patients with Ulcerative Colitis. PLoS One 2020;15(4):e0231988.

17. He W, Ruan $Y$, Yuan $C$, et al. High neutrophil-to-platelet ratio is associated with hemorrhagic transformation in patients with acute ischemic stroke. Front Neurol 2019;10:1310.
18. Wang $C$, Wang $M$, Zhang $X$, et al. The neutrophil-tolymphocyte ratio is a predictive factor for the survival of patients with hepatocellular carcinoma undergoing transarterial chemoembolization. Ann Transl Med 2020;8(8):541.

19. Mouchli $M$, Reddy $S$, Gerrard $M$, et al. Usefulness of neutrophil-to-lymphocyte ratio (NLR) as a prognostic predictor after treatment of hepatocellular carcinoma." Review article. Ann Hepatol 2021;22:100249.

20. Hu B, Yang $X R, X u Y$, et al. Systemic immune-inflammation index predicts prognosis of patients after curative resection for hepatocellular carcinoma. Clin Cancer Res 2014;20(23):6212-22.

21. Liao $C K, Y u$ YL, Lin $Y C$, et al. Prognostic value of the C-reactive protein to albumin ratio in colorectal cancer: An updated systematic review and meta-analysis. World J Surg Oncol 2021;19(1):139.

22. Ren Y, Fan X, Chen G, et al. Preoperative C-reactive protein/ albumin ratio to predict mortality and recurrence of patients with hepatocellular carcinoma after curative resection. Med Clin (Barc) 2019;153(5):183-90. 